Southern Illinois University Carbondale

OpenSIUC

Publications

Department of Zoology

$7-2007$

\title{
A New Species of Dipetalonema (Filarioidea: Onchocercidae) from Ateles chamek from the Beni of Bolivia
}

Juliana Notarnicola

Centro de Estudios Parasitologicos y de Vectores

F. Agustin Jimenez-Ruiz

Southern Illinois University Carbondale, agustinjz@siu.edu

Scott Lyell Gardner

University of Nebraska - Lincoln

Follow this and additional works at: http://opensiuc.lib.siu.edu/zool_pubs

Published in the Journal of Parasitology, Vol. 93, No. 3 (2007): 661-667. Copyright 2007, American Society of Parasitologists. Used by permission.

\section{Recommended Citation}

Notarnicola, Juliana, Jimenez-Ruiz, F. A. and Gardner, Scott L. "A New Species of Dipetalonema (Filarioidea: Onchocercidae) from Ateles chamek from the Beni of Bolivia." (Jul 2007).

This Article is brought to you for free and open access by the Department of Zoology at OpenSIUC. It has been accepted for inclusion in Publications by an authorized administrator of OpenSIUC. For more information, please contact opensiuc@lib.siu.edu. 


\title{
A NEW SPECIES OF DIPETALONEMA (FILARIOIDEA: ONCHOCERCIDAE) FROM ATELES CHAMEK FROM THE BENI OF BOLIVIA
}

\author{
Juliana Notarnicola, F. Agustín Jiménez ${ }^{\star}$, and Scott L. Gardner \\ Centro de Estudios Parasitológicos y de Vectores-CEPAVE-CONICET-UNLP, Calle 2 Número 584 (1900) La Plata, Argentina. \\ e-mail: julinota@cepave.edu.ar
}

\begin{abstract}
We describe a new species of Dipetalonema occurring in the body cavity of Ateles chamek (Humboldt, 1812) from north-central Bolivia. Morphologic characters serving to separate Dipetalonema yatesi $\mathrm{n}$. sp. from known forms include a vagina vera with a simple tube and thin walls and a left spicule, which possesses a handle shorter than the lamina (ratio 2.7); the latter displays an anterior membranous alae similar in length to the terminal flagellum, a distal extremity of the left spicule within a simple hook and a membrane, phasmids at the basis of the lappets, and heterogeneous muscles occupying the whole cavity. Dipetalonema yatesi n. sp. can be separated from Dipetalonema robini, Dipetalonema gracile, and Dipetalonema graciliformis, between other characters, in having a simple vagina vera instead of a sinuous one, and from Dipetalonema caudispina and Dipetalonema freitasi in having the lamina of the left spicule divided in a membranous alae and a terminal flagellum.
\end{abstract}

While carrying out expeditionary research on the biodiversity of mammals and their parasites of Bolivia by joint collecting teams from the Museum of Southwestern Biology, the American Museum of Natural History, and the Colección Boliviana de Fauna, small- and medium-sized mammals were collected and examined for parasites (Gardner and Campbell, 1992; Anderson, 1997). During our work in the Departamento de Beni in 1985, one of us (S.L.G.) had the opportunity to examine a specimen of Ateles sp. É. Geoffroy Saint-Hilaire, 1806 (Primates: Cebidae) that had been collected by local Chimane hunters. Herein, we report on the filarioid nematodes discovered at necropsy of this single individual spider monkey.

Spider monkeys, Ateles spp., have a wide distribution in the Neotropics, with Ateles geoffroyi Kuhl, 1820, reaching a northern limit of its range in the lowlands of southern Veracruz State in Mexico. Six species are included in the genus, with only Ateles chamek (Humboldt, 1812) known to be from Bolivia (Anderson, 1997). Ateles chamek usually occurs in undisturbed primary forests in southeastern Peru, western Brazil, and in the lowlands of eastern Bolivia in the Amazon basin (Anderson, 1997; Eisenberg and Redford, 1999).

Several gastrointestinal parasites, e.g., pinworms, hookworms, whipworms, and protozoans, have been reported from species of Ateles in Panama, Guyana, and other Central and South American countries (Hugot et al., 1996; Thoisy et al., 2000; Phillips et al., 2004). Filarioid nematodes were reported from the body cavity of Ateles spp. by Freitas (1943) and Caballero (1947). From Bolivia, Freitas (1964) first reported $D i$ petalonema gracile (Rudolphi, 1809) in Cebus capucinus (L.); Karesh et al. (1998) also reported this species from a single specimen of A. chamek (originally mentioned as Ateles paniscus chamek; see Anderson, 1997) from Parque Nacional Noel Kempff Mercado in northeastern Bolivia. Karesh et al. (1998) also reported an unidentified species of Strongyloides, lice eggs, and evidence of previous infections with spirochaetes (Leptospira sp.) and viruses, including those causing encephalitis and yellow fever.

\section{MATERIALS AND METHODS}

A single specimen of $A$. chamek shot by hunters was prepared as a study specimen by Luis Ruedas and examined for parasites by S.L.G.

Received 3 June 2006; revised 23 August 2006, 25 October 2006; accepted 22 November 2006

* The Harold W. Manter Laboratory of Parasitology, University of Nebraska State Museum, Lincoln, Nebraska 68588-0514. on 28 August 1985. The thoracic and abdominal cavities of the monkey were searched for parasites following the general methods of Gardner (1996). Filarioid nematodes, found only among the mesenteries in the abdominal cavity, were washed in saline, fixed in cold $10 \%$ formalin solution, and stored in 70\% ethanol (see Gardner, 1996). For light microscopy, specimens were cleared in lactophenol and mounted on a microscope slide. A cross section of the anterior end of a female was made to obtain an en face view. Lateral chords and the disposition of the muscles were observed in a midbody cross section from both male and female worms. Microfilariae were obtained via dissection of the uterus of a mature female specimen. Drawings were made with a Wild microscope equipped with a drawing tube.

Measurements were taken directly from specimens, either with an ocular micrometer or with digital measuring software (Jandel Sigma Scan Pro, San Rafael, California; Albinger et al., 1995), with a Zeiss Ultraphot microscope. Measurements are given in micrometers, unless otherwise stated. For each character, we give the mean value followed by the standard deviation and the range in parentheses (Sokal and Rohlf, 1995). We also give the measurements from 1 small-sized specimen and note that it is a juvenile male.

Specimens prepared for scanning electron microscopy (SEM) were treated with osmium-thiocarbohydrazide-osmium-thiocarbohydrazideosmium (OTOTO), dehydrated in $100 \%$ ethanol, dried to a nonliquid state by critical-point drying using $\mathrm{CO}_{2}$, attached to an SEM stub, and sputter-coated with gold palladium.

For comparative purposes, we examined specimens of Dipetalonema gracile collected from Ateles chamek (syn. Ateles paniscus chamek; see Anderson, 1997) from Parque Nacional Noel Kempff Mercado, Bolivia. The specimens are deposited in the U.S. National Parasite Collection (USNPC86233).

\section{DESCRIPTION \\ Dipetalonema yatesi $\mathrm{n}$. sp. \\ (Figs. 1-32)}

General: Long, whitish worms. Anterior end blunt, posterior end tapering to a point. Vulva at level of esophagus; esophagus divided into anterior muscular and posterior glandular portions. Papillae on cephalic plate arranged in a dorso-ventrally flattened rectangle. Caudal extremity with subterminal lappets.

Male: Labial papillae rectangular pattern 50 by 20; cephalic papillae rectangular pattern 90 by 35 (Figs. 1, 2, 23). Additional male, 60 by 25 and 90 by 40 , respectively. One male with labial papilla displaced to axis of buccal opening (Fig. 24). Cuticular axis of right spicule with subterminal curve; distal extremity ending in a simple hook with a membrane (Figs. 8, 10,11). Left spicule with handle shorter than lamina; lamina with proximal membranous alae and distal filament or flagellum; membranous alae and flagellum similar in length (Figs. 4, 6, 7). Gubernaculum present. Area rugosa, extending through coiled region, including tail, formed by rows of small longitudinal crests (Fig. 26). Precloacal area rugosa consisting of 1 ventral band (Fig. 28); postcloacal area rugosa formed by 2 subventral bands; left band ends far more posteriorly than right band (Fig. 25). Five pairs of genital papillae arranged in 2 adcloacal rows, a single precloacal papilla, and a sub- 


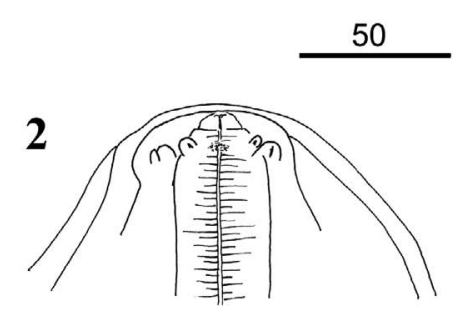

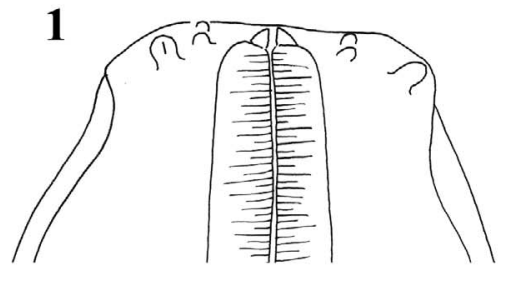
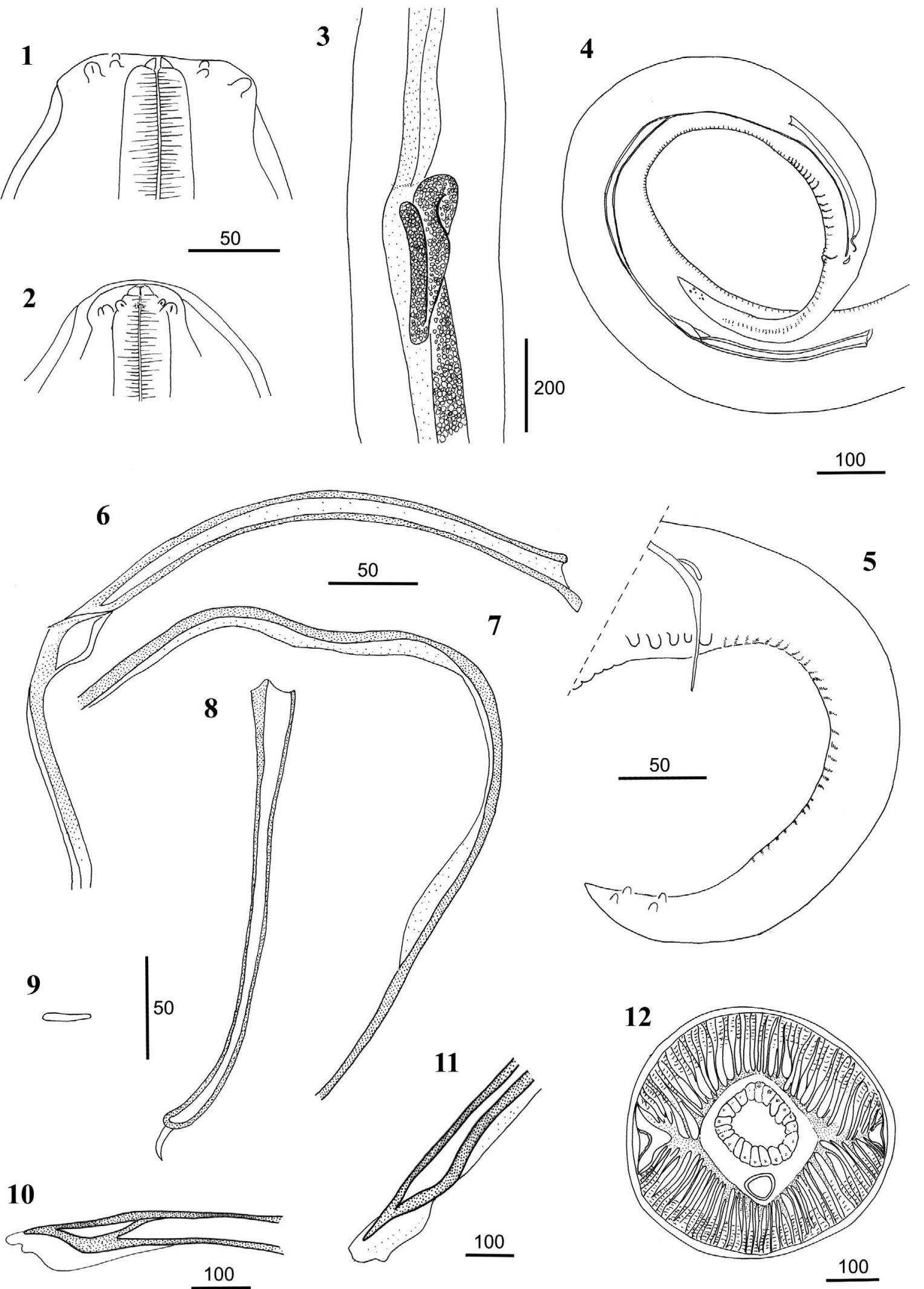

Figures 1-12. Dipetalonema yatesi $\mathrm{n}$. sp. Male. (1-2) Anterior extremity median and lateral views, respectively. (3) Detail of anterior end of testis and the esophagus-intestinal junction. (4) Posterior extremity, lateral view, showing the entire left spicule, the right spicule, and the gubernaculum. (5) Tail, lateral view. (6-7) Left spicule. (6) Handle, lateral view. (7) Lamina showing the membranous alae and the beginning of the flagellum, lateral view. (8) Right spicule, lateral view. (9) Gubernaculum. (10-11) Distal extremity of a dissected right spicule. (10) Dorsolateral view. (11) Dorsal view. (12) Midbody cross section showing the muscles. 

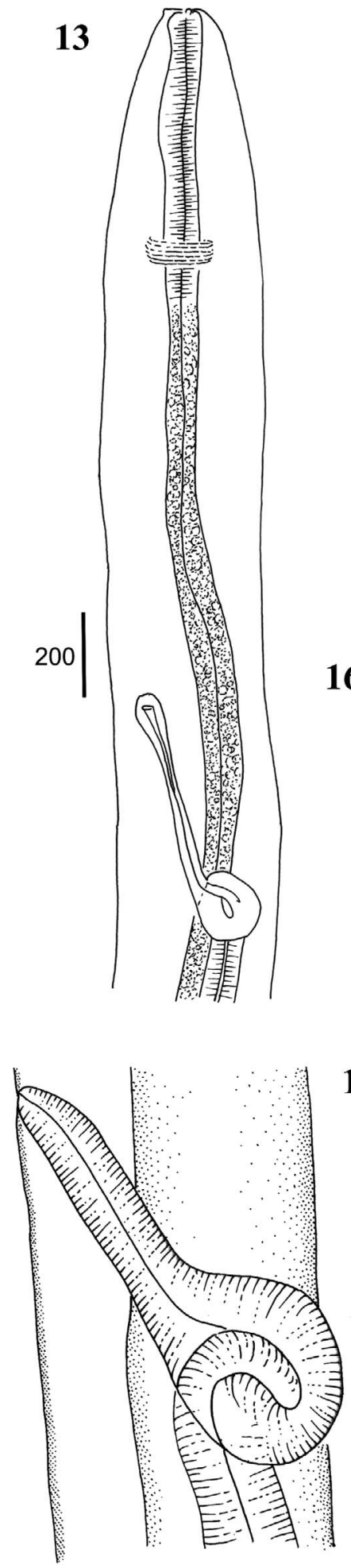

200

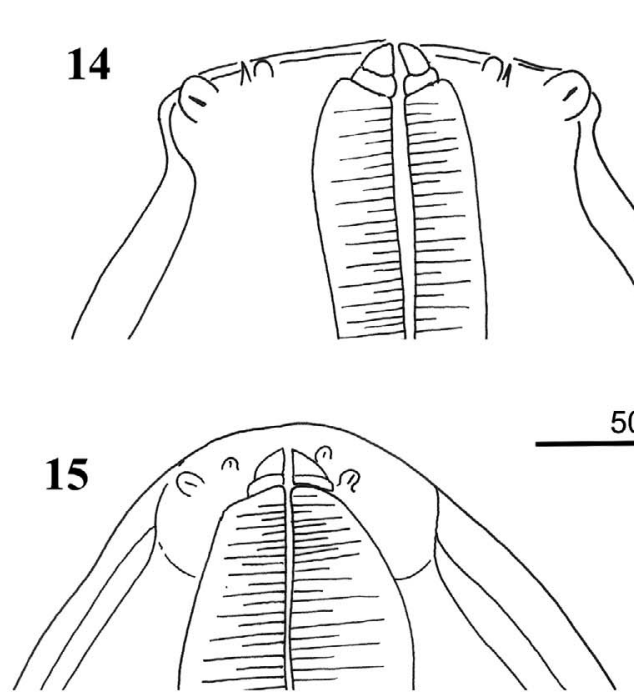

16

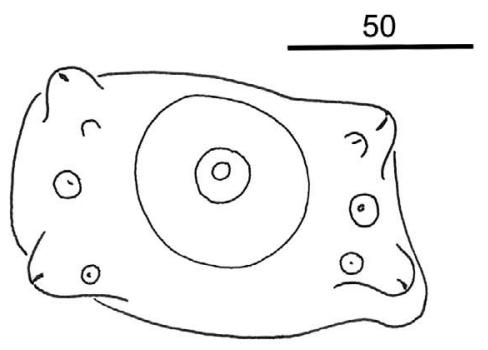

18

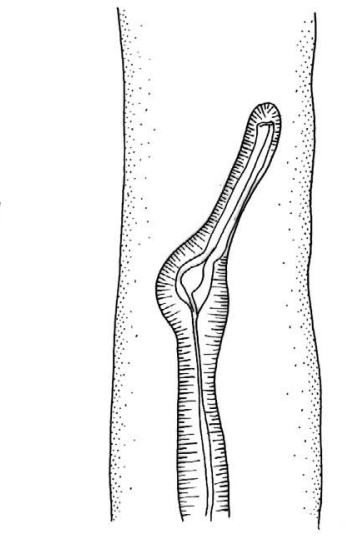

200
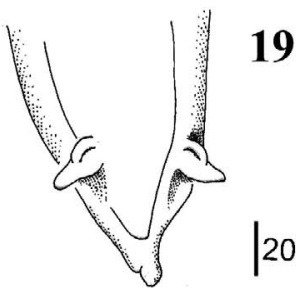

19

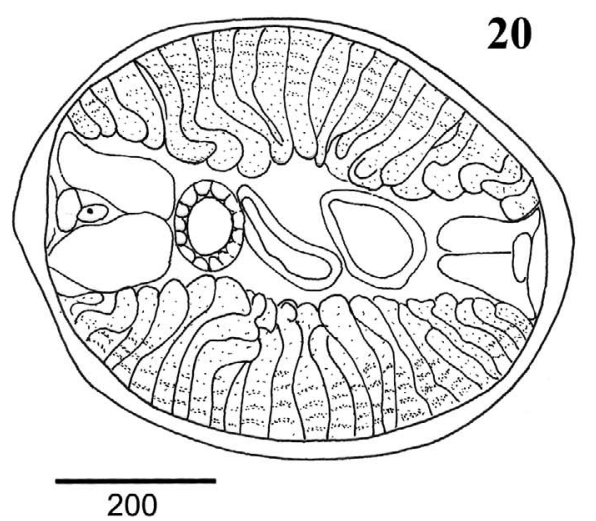

21

Figures 13-22. Dipetalonema yatesi n. sp. Female. (13) Anterior end showing relative position of nerve ring and vulva. (14-16) Anterior extremity, median, lateral, and en face views, respectively. (17-18) Vagina vera, lateral and ventral views. (19) Posterior extremity, ventral view showing the lappets. (20) Cross section posterior to the vulva. (21) Tail, lateral view. (22) Uterine microfilaria. 

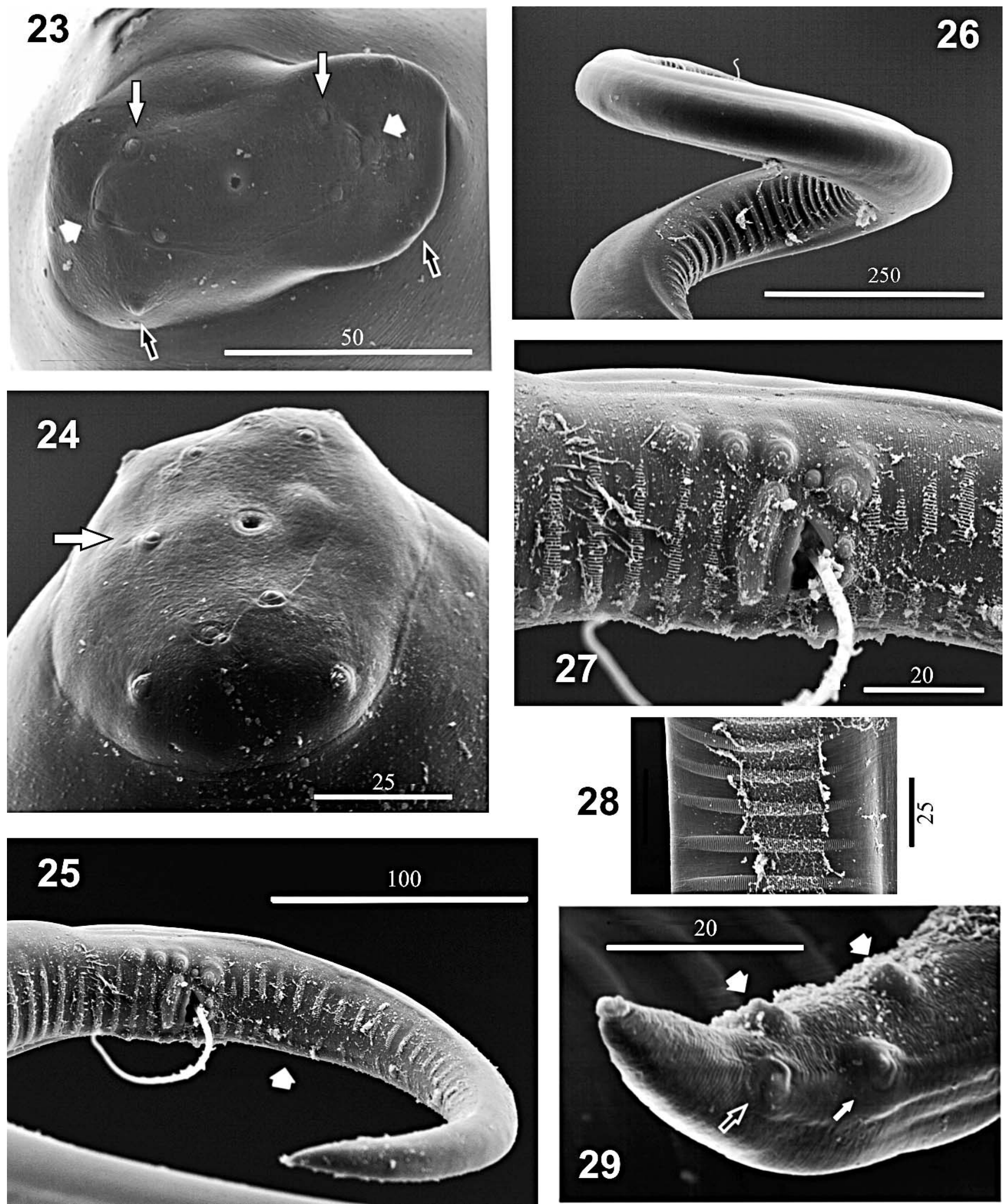

FIGURES 23-29. Dipetalonema yatesi $\mathrm{n}$. sp. Male scanning electron photography. (23-24) En face view of the anterior end showing labial papillae (white thin arrows), cephalic papillae (black thin arrows), and amphids (white thick arrows). (24) Male with an abnormal distribution of labial papillae (white arrow). (25) Posterior extremity showing the 2 subventral bands of the postcloacal area rugosa, the white arrow marks the end of the right band. (26) Posterior extremity coiled showing the area rugosa. (27) Cloacal region showing the papillae, the precloacal area rugosa constituted with 1 band, and the postcloacal area rugosa with 2 subventral bands. (28) Detail of the area rugosa at midlength. (29) Posterior extremity showing the lateral papillae (thin white arrow), the median papillae (thick arrows), and the lappets (black arrow). 

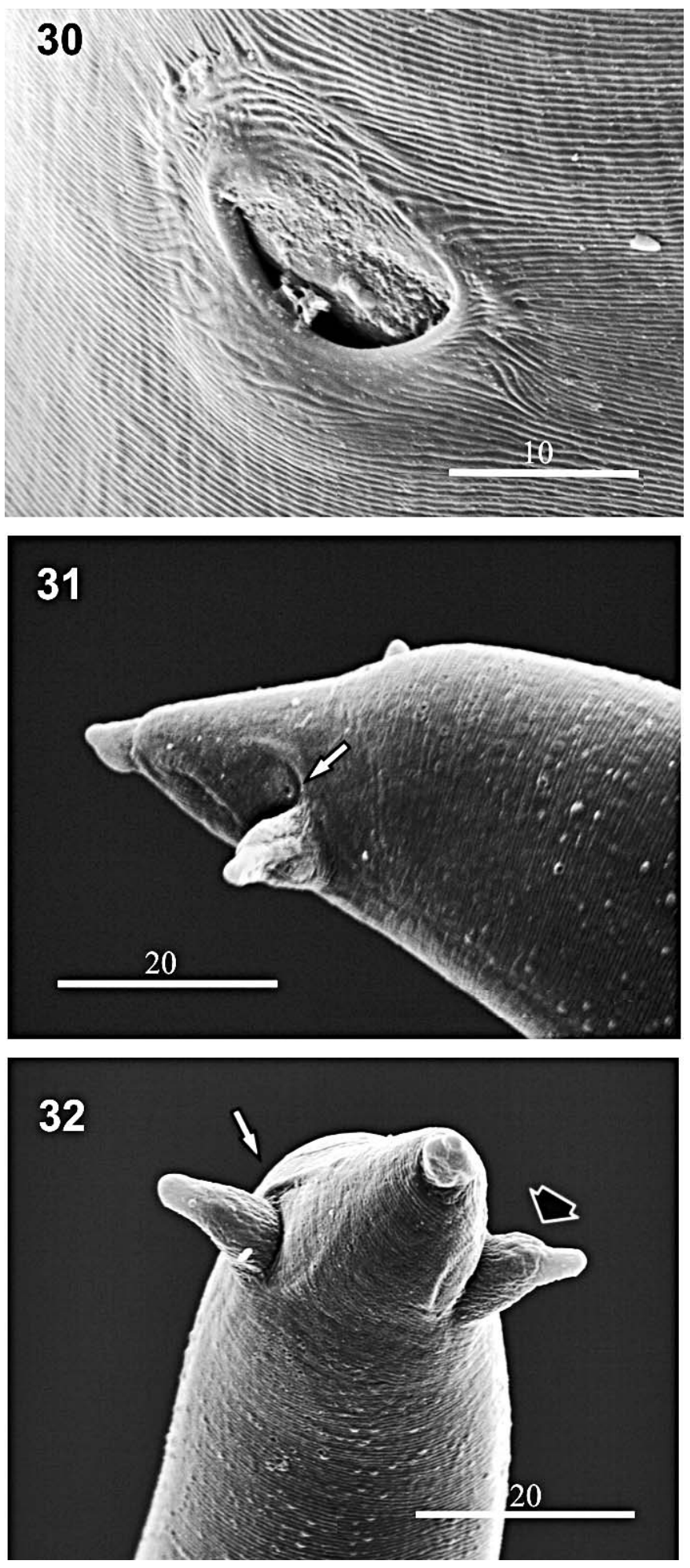

FiguRES 30-32. Dipetalonema yatesi n. sp. Female scanning electron photography. (30) Detail of vulva. (31-32) Posterior extremity showing the caudal lappets (black arrow), and the phasmid opening (white arrow), lateral and ventral views, respectively. medial postcloacal pair (Fig. 27). Four caudal papillae, 2 submedial and 4 sublateral (Fig. 29). Caudal lappets situated 25-35 from posterior end. Large muscles in heterogeneous packs, smaller in dorsal and ventral fields, longer at lateral fields, occupying the whole cavity and drawing up the boundaries of a rhomb (Fig.12).

Holotype: Length $111.9 \mathrm{~mm}$; width 272; nerve ring 150 from apex; buccal capsule 8 long and 17 wide; esophagus 2,993 long; muscular portion 400 long; tail 340 long; left spicule 1,070 long, handle 320 long; right spicule 180 long. Spicular ratio 5.94. Area rugosa $16.02 \mathrm{~mm}$ long.

Paratypes (based on 8 specimens): Length $99 \pm 10.3 \mathrm{~mm}$ (81.9111.1); width $309 \pm 11$ (303-333); nerve ring $233 \pm 22$ (200-250) from apex; buccal capsule $7.1 \pm 1.4$ (5-9) long and $20 \pm 0.5(20-21)$ wide; esophagus $2,719 \pm 243(2,242-2,999)$; long, muscular portion $485 \pm 59$ (388-550); tail $368 \pm 34(340-440)$ long; left spicule 1,154 $\pm 80(1,020-1,260)$ total length, handle $307 \pm 20(270-340)$ long, membranous alae $466 \pm 57$ (400-500) long, and flagellum $436 \pm 58$ (370-480) long; right spicule $242 \pm 15$ (210-260) long; spicular ratio $4.77 \pm 0.46$ (4.2-5.7); gubernaculum $22 \pm 3.7$ (20-30) long. Area rugosa $10.5 \pm 1.1(9-12) \mathrm{mm}$ long.

Juvenile male: Length $54.43 \mathrm{~mm}$; nerve ring 150 from apex; buccal capsule 5 long by 20 wide; esophagus 2,484 long; muscular portion 300 long; tail 350; left spicule 1,250 long, handle 300 long; membranous alae and flagellum 700 and 250, respectively; right spicule 270 long. Spicular ratio 4.62. Area rugosa $8.84 \mathrm{~mm}$ long.

Female: Labial papillae, rectangular pattern 40 by 25 ; cephalic papillae, rectangular pattern 70 by 40 ; other female, 55 by 25 and 90 by 40; additional female 60 by 25 and 95 by 40, respectively (Figs. 1416). Vagina vera consisting of a simple straight tube surrounded by thin walls and ending in a semicircular vulva (Figs. 13, 17, 18, 30). Lateral chords conspicuous (Fig. 20). Simple caudal lappets with a broaden base. Phasmid opening at the base of the lappets (Figs. 19, 31, 32).

Allotype: Length $237.3 \mathrm{~mm}$; width 339; buccal capsule 10 long and 20 wide; nerve ring 250 from apex; esophagus 3,175 long; muscular portion 350 long; tail 635 long. Vulva at level of esophagus 588 from anterior end; vagina 269 long and 92 wide; ovijector 4,242 long. Caudal lappets 10 long, situated 30 from posterior end.

Paratypes (based on 2 complete specimens, 3 anterior extremities, and 2 posterior extremities): Length 239.6 and $254.2 \mathrm{~mm}$; width 530 \pm 40 (496-575); buccal capsule $8.5 \pm 1.9(6-10)$ long and $20.7 \pm 0.95$ (20-22) wide; nerve ring $268 \pm 37$ (226-300) from apex; esophagus $4,314 \pm 653(3,569-4,787)$ long, muscular portion $687 \pm 86(560-$ $750)$ long; tail $775 \pm 47$ (710-810) long. Vulva $1,187 \pm 362$ (7501,636) from anterior end.

Microfilariae: Body fusiform. Anterior extremity rounded with a cephalic hook, short cephalic space. Tail attenuated, tip tail anucleated. Large sheath. Measurements based on uterine microfilariae from 2 different females $(n=13): 166.2 \pm 4.2(158-172)$ long; $5.53 \pm 0.35$ (4.86) wide. Length of sheath $206.46 \pm 19.7$ (159-226) and $8.7 \pm 1.35$ (6.1-10.6) wide.

\section{Taxonomic summary}

Type host: Chamek Spider Monkey Ateles chamek (Humboldt, 1812) collected 28 August 1985

Type locality: $14^{\circ} 42.5^{\prime} \mathrm{S} ; 67^{\circ} 04^{\prime} \mathrm{W} ; 45 \mathrm{~km}$ north by road of Yacuma, Beni, Bolivia.

Site of infection: Abdominal cavity.

Specimens deposited: Holotype male HWML48375; allotype female HWML48376, paratypes HWML48377 through HWML48380 (9 males and 5 females).

Etymology: The species is named for Dr. Terry L. Yates, along with Sydney Anderson, 1 of the primary leaders of our work on diversity of mammals of Bolivia.

\section{Remarks}

Dipetalonema yatesi n. sp. resembles Dipetalonema caudispina (Molin, 1858) in having a vagina vera with a simple straight tube (Bain et al., 1986) but differs in that females possess a vagina vera with thin walls and the vulva opens more posterior (mean of 1,187 vs. $400-420$ $\mu \mathrm{m})$. In males, the left spicule has a terminal flagellum, and the postcloacal area rugosa displays 2 subventral bands of small crests, instead of 1 on the left side. 
Both species, D. yatesi n. sp. and D. gracile (Rudolphi, 1809) possess 2 subventral bands of postcloacal area rugosa and a similar shaped right spicule; however, $D$. gracile display a bifid end of the right spicule, and the membranous alae of the left spicule is longer than the flagellum. The new species also has a vagina vera with a simple tube, instead of a sinuous one, and a longer microfilaria (range of 166-172 vs. 125-145 $\mu \mathrm{m}$ ) (Bain et al., 1986; J. Notarnicola, per. obs.).

Dipetalonema yatesi n. sp. differs from D. graciliformis Freitas, 1964, in having a longer right band of the postcloacal area rugosa, a smaller handle-lamina ratio of the left spicule (2.7 vs. 3.5$)$, a simple vagina vera, a longer tail (710-810 vs. $250-300 \mu \mathrm{m})$, and a much longer microfilaria (166-172 vs. 93-115 $\mu \mathrm{m})$. In addition, the tails of the microfilariae are tapering and without obvious nuclei compared with those of D. graciliformis, which are stout and have nuclei at the tips (Freitas, 1964; Bain et al, 1986).

The new species can be separated from D. freitasi Bain, Diagne and Muller, 1987, by possessing a postcloacal area rugosa (not present in D. freitasi) and the presence of a terminal flagellum on the left spicule (not present in D. freitasi). Moreover, D. yatesi n. sp. has females with longer tails (mean of $635 \mu \mathrm{m} v s .510 \mu \mathrm{m}$ ) and much longer microfilaria (166-172 vs. 100-107 $\mu \mathrm{m}$ ) (Bain et al., 1987).

Dipetalonema yatesi n. sp. resembles to D. robini Petit, Bain and Roussilhon, 1985, in the shape and size of the spicules and the microfilaria, but the new species displays a distal extended membrane of the right spicule; 2 ventral bands in the postcloacal area rugosa, compared with 1 in $D$. robini; and a simple tube of the vagina vera instead of a sinuous one. Phasmids of the new species have a simple opening at the base of the lappets instead of presenting a bifid lappet with the opening of the phasmid on a small posterior tubercle (Petit et al., 1985; Bain et al., 1987). Scanning electron micrographs confirm that the openings of the phasmids are on the base of the lappets, and that lappets are a simple tubercle with a broad base (see Figs. 31, 32).

\section{DISCUSSION}

Dipetalonema yatesi n. sp. can be separated from the other Dipetalonema species by the combination of the following characters: the presence of a simple tube of the vagina vera, similar length of the membranous alae and the flagellum on the left spicule, a simple hook on the distal end of the right spicule, 2 postcloacal bands of the area rugosa, heterogeneous muscles occupying the whole cavity, and microfilaria with a large sheath and anucleated tip tail. However, some of these characters are shared with other species of Dipetalonema, i.e., the ratio of the left spicule with $D$. robini, the disposition of the postcloacal area rugosa with $D$. gracile and $D$. graciliformis, and the simple vagina vera with $D$. caudispina. Following the sequences of character evolution stated by Bain et al. (1987), D. yatesi $\mathrm{n}$. sp. could be an intermediate form between $D$. freitasi and $D$. robini, when the shape of the left spicule and male musculature characters are considered, or between $D$. caudispina and $D$. freitasi, when the shape of the vagina vera is considered. A final statement on these points awaits a phylogenetic analysis of the species in this genus.

The finding of 1 male, which is much shorter than the other specimens in the same lot and with the same characters, suggests this is a juvenile. This specimen shows no sign of molting, as in the juveniles of other filarioid species (Guerrero et al., 2002; Notarnicola, 2005).

The first record of filarioid nematodes from monkeys in Bolivia was the report of $D$. gracile by Freitas (1964). The locality was not recorded and remains unknown, but was probably somewhere in southeastern part of the country because the material was collected by the Comissão de Estudos Epidemiológicos sôbre Leishmaniose Visceral Americana (CEELVA) (Freitas, 1964). The other report, mentioned above, of D. grac- ile was published by Karesh et al. (1998) for Ateles chamek (syn. A. paniscus chamek; see Anderson, 1997) from primary forest in the Parque Nacional Noel Kempff Mercado in the eastern department of Santa Cruz. These specimens are available from the USNPC (USNPC86233).

The occurrence of $D$. gracile in several samples of Bolivian spider monkeys suggests that this parasite is common. However, more detailed work is conducted on the biodiversity of parasites of Bolivia primates, data on prevalence and intensity of these parasites in natural populations will be missing. Pathogenesis of these nematodes in Ateles spp. is uncertain, but some negative influence was indicated in the report by Karesh et al. (1998) in which, from an old individual male monkey, hundreds of filarial worms were found in the abdominal cavity, with many attached to the serosa of the intestines.

In Bolivia, as deforestation continues and crowding of the monkeys increases in the remaining patches of primary lowland forest, this nematode may play a significant role in the health and perhaps long-term viability of monkeys remaining. Although the life cycle is unknown for D. yatesi at this time, the vector is assumed to be some kind of an hematophagous dipteran, most likely a species of Ceratopogonidae (Eberhard et al., 1979). Hyperinfections of these nematodes can probably be expected to result from increased numerical density of hosts. We encourage ecologists and forest and wildlife managers in Bolivia to take special care to collect data on parasites of any primate species available. The example of data taking on both living and dead primates by Karesh et al. (1998) is a good one to follow in this regard.

\section{ACKNOWLEDGMENTS}

We thank the Colección Boliviana de Fauna of the Museo de Historia Natural in La Paz for long term logistic support. We also thank Kit Lee from the Scanning Electron Microscopy Laboratory-University of Nebraska for his help; María Cristina Estivaríz from CEPAVE, for the drawings; and Pat Pillit from USNPC, Beltsville, Maryland, for the material loaned. This study was partially funded by a Beca para Estadías Breves en el Extranjero, from Consejo Nacional de Investigaciones Científicas y Técnicas-CONICET-Argentina to J.N. and from the Harold W. Manter Laboratory-University of Nebraska-USA and by U.S. National Science Foundation Grants (BSR8612329, BSR9024816, DEB9496263, and DEB9631295 to S.L.G.).

\section{LITERATURE CITED}

Albinger, G., A. Fontes Jr., K. Kerle, N. Link, A. Macy, and S Simon. 1995. SigmaScan Pro. Jandel Scientific Software, San Rafael, California.

Anderson, S. 1997. Mammals of Bolivia: Taxonomy and distribution. Bulletin of the American Museum of Natural History 231: 1-652.

Bain, O., G. Petit, and L. Rosales-Loesener. 1986. Filaires de Singes sud-américains. Bulletin du Museum National de Histoire Naturelle, Paris $4^{\text {a }}$ serie 8, sectión A, 3: 513-542.

, M. Diagne, And R. Muller. 1987. Une cinquième filaire du genre Dipetalonema, parasite de singes sud-américains. Annales de Parasitologie Humaine et Compareé 62: 262-270.

Caballero, E. 1947. Algunas filarias de mamíferos y de reptiles de las Repúblicas de Colombia y Panamá. Anales del Instituto Biologico de la Universidad Nacional de México 18: 169-188.

Eberhard, M. L., R. C. Lowrie JR., AND T. C. Orihel. 1979. Development of Dipetalonema gracile and D. caudispina to the infective stage in Culicoides hollensis. Journal of Parasitology 65: 89-95.

EisenberG, J. F., AND K. H. RedFORD. 1999. Mammals of the Neotropics: The central Neotropics. Ecuador, Peru, Bolivia, Brazil. Volume 3. University of Chicago Press, Chicago, Illinois, 609 p.

FreitAs, J. F. T. 1943. Estudios sobre nematodeos filarideos Dipetalo- 
nema caudispina (Molin, 1858). Memorias do Instituto Oswaldo Cruz 38: 361-372.

1964. Achegas Helminthologicas. Revista do Ciencias Biológicas, Belèm 3: 3-40.

GARDNER, S. L. 1996. Essential techniques for collection of parasites during surveys of mammals. In Measuring and monitoring biological diversity-Standard methods for mammals, D. Wilson, R. Cole, J. D. Nichols, P. Rudran, and M. Foster (eds.). Smithsonian Institution Press, Washington, D.C., p. 291-298.

-, AND M. L. CAmpbell. 1992. Parasites as probes for biodiversity. Journal of Parasitology 78: 596-600.

Guerrero, R., C. Martin, S. L. Gardner, And O. Bain. 2002. New and known species of Litomosoides (Nematoda: Filarioidea): Important adult and larval characters and taxonomic changes. Comparative Parasitology 69: 177-195.

Hugot, J. P., S. L. Gardner, And S. Morand. 1996. The Enterobiinae subfam. nov. (Nematoda, Oxyurida) pinworm parasites of primates and rodents. International Journal for Parasitology 26: 147-159.

Karesh, W. B., R. B. Wallace, R. L. E. Painter, D. Rumiz, W. E.
Braselton, E. S. Dierenfeld, And H. Puche. 1998. Immobilization and health assessment of free-ranging black spider monkeys (Ateles paniscus chamek). American Journal of Primatology 44: 107-123.

NotARniCOLA, J. 2005. Description of adults and fourth-stage larva of Litomosoides navonae $\mathrm{n}$. sp. (Nematoda: Onchocercidae), a parasite of five species of sigmodontine rodents from northeastern Argentina. Systematic Parasitology 62: 171-183.

Petit, G., O. Bain, And C. Roussilhon. 1985. Deux nouvelles Filaires chez un Singe Saimiri sciureus au Guyana. Annales de Parasitologie Humaine et Compareé 60: 65-81.

Phillips, K. A., M. E. HaAs, B. W. Grafton, and M. Yrivarren. 2004 Survey of the gastrointestinal parasites of the primate community at Tambopata National Reserve, Peru. Journal of Zoology 264: 149-151.

SOKAL, R. R., AND F. J. Rohlf. 1995. Biometry: The principles and practice of statistics in biological research, 3rd ed. W. H. Freeman, New York, New York, 887 p.

Thoisy, B. De, J. C. Michel, I. Vogel, And J. C. Vié. 2000. A survey of hemoparasite infections in free-ranging mammals and reptiles in French Guiana. Journal of Parasitology 86: 1035-1040. 